\title{
Сравнительный анализ антоциановых соединений плодов рябины черноплодной различных сортов методом ВЭЖХ
}

\author{
Логвинова Е.Е. ${ }^{1}$, Брежнева Т.А. ${ }^{1}$, Сливкин А.И. ${ }^{1}$, \\ Перова И.Б. ${ }^{2}$, Эллер К.И. ${ }^{2}$ \\ ${ }^{1}$ ФББОУ ВО «Воронежский государственный университет», Воронеж \\ ${ }^{2}$ ФГБУН «ФИЦ питания и биотехнологии», Москва
}

Поступила в редакцию 16.12.2016 г.

\begin{abstract}
Методом ВЭЖХ определено суммарное содержание и специфические профили индивидуальных антоцианинов плодов аронии черноплодной различных сортов. Хроматографические профили извлечений из всех сортов оказались сходны с преобладанием цианидин-3-галактозида в качестве основного ингредиента. Общее количество антоцианов составило от $0,98 \%$ (Алтайская крупноплодная) до 3,70\% (Мичуринская).
\end{abstract}

Ключевые слова: плоды рябины черноплодной, сумма антоцианинов, профиль антоцианинов, ВЭЖХ-ДМД-МС-ТОF.

\section{Comparative analysis of compounds of fruits anthocyanin black chokeberry different varieties HPLC}

\author{
Logvinova E.E ${ }^{1}$, Brezhneva T.A ${ }^{1}$, Slivkin A.I ${ }^{1}$, \\ Perova I.B. ${ }^{2}$, Eller K.I. ${ }^{2}$ \\ ${ }^{1}$ Voronezh State University, Voronezh \\ ${ }^{2}$ FIZ Food and Biotechnology, Moscow
}

Anthocyanins (from the Greek Anthos -. Flower, kyanos - blue, azure) belong to a large and widespread group of plant flavonoids. Anthocyanins are water soluble pigments neplastidnymi concentrated in the vacuoles of cells. One of the modern instrumental methods used for qualitative and quantitative analysis of minor bioactive substances of plant origin is a high performance liquid chromatography (HPLC). In this paper, the HPLC method was used to study the composition of fruit anthocyanins black chokeberry different varieties.

It has been found that the chromatographic profiles of extracts from fruits antotsiansoderzhaschih chokeberry four varieties studied sufficiently close to the predominance cyanidin-3-galactoside as the main ingredient. The total content of anthocyanins in the fruit ranged from $0.98 \%$ (Altai large-fruited) to $3.70 \%$ (Michurinskaya).

Keywords: Black chokeberries, total anthocyanins, anthocyanin profiles, HPLC-DAD-MS-TOF.

\section{Введение}

Антоцианы (от греч. Anthos - цветок, kyanos - синий, лазоревый) принадлежат к большой и широко распространенной группе растительных флавоноидов. Антоцианы являются непластидными водорастворимым пигментами, сосредоточены в 
вакуолях клеток и окрашивают плоды, листья, лепестки в цвета от розового до черно-фиолетового [1,2].

Антоцианины являются гликозидными производными антоцианидиновых агликонов. Структура шести основных антоцианидинов, наиболее распространенных в растительном мире, приведена на рис. 1.

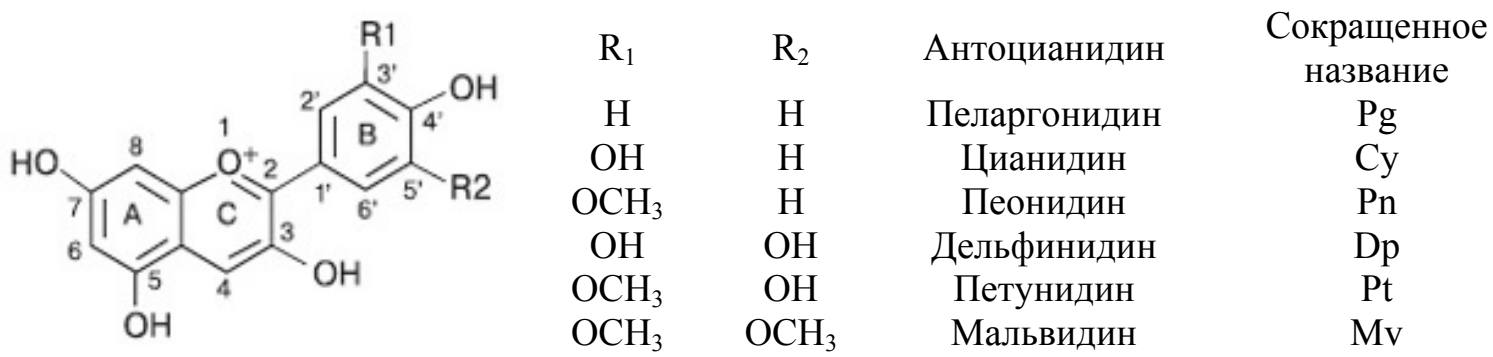

Рис. 1. Структура агликонов антоцианов - антоцианидинов.

Одним из современных инструментальных методов, который используется для качественного и количественного анализа минорных биологически активных веществ растительного происхождения является высокоэффективная жидкостная хроматография (ВЭЖХ).

В настоящей работе метод ВЭЖХ был применен для исследования антоцианового состава плодов рябины черноплодной различных сортов.

Учитывая вариабельность состава биологически активных веществ растений в зависимости от почвенно-климатических условий их произрастания и сортовых особенностей [3], целью работы являлся сравнительный анализ качественного состава и количественного содержания антоциановых соединений плодов рябины черноплодной различных сортов.

\section{Эксперимент}

В качестве объектов исследования были выбраны образцы высушенных плодов рябины черноплодной сортов «Мичуринская», «Викинг», «Вениса» и «Алтайская крупноплодная», заготовленных от культивируемых растений в период сентябрь - октябрь 2015 г. Лекарственное растительное сырье было стандартизовано согласно требованиям ГФ XIII [4]. Сушку образцов осуществляли в естественных условиях (воздушно-теневая сушка).

На первом этапе исследования провели качественный анализ антоцианинового состава плодов рябины черноплодной различных сортов методом ВЭЖХ.

Извлечение антоцианов из сырья проводили по следующей методике: к 2.0 г измельченных плодов рябины черноплодной добавляли $20 \mathrm{~cm}^{3}$ воды. Экстракцию проводили на УЗ бане при комнатной температуре в течение 15 минут. Аликвоту в 1.5-2 $\mathrm{cm}^{3}$ полученного экстракта центрифугировали при 15000 об/мин в течение 10 мин [5].

При определении профиля индивидуальных антоцианов использовалась система ВЭЖХ «Agilent 1100» с диодно-матричным спектрофотометрическим детектором (ДМД) и времяпролетным масс-спектрометрическим детектором «Agilent 6200 series» (ВЭЖХ-MC/TOF). Неподвижная фаза: колонка Phenomenex Luna C18 250x4.6 мм, $5 \mu$ м. Подвижная фаза: А - $1.0 \%$-ный водный раствор муравьиной кислоты и В ацетонитрил. Ступенчатый градиент: 0 мин - 10\% В, 10 мин - 12\% В, 20 мин $-15 \%$ В, 30 мин - 20\% В, 40 мин - 30\% В, 50 мин - 40\% В, 51-60 мин - 10\% В. Общее вре- 
мя анализа 60 мин. Скорость потока подвижной фазы $0.5 \mathrm{~cm}^{3} /$ мин. Температура колонки $40^{\circ} \mathrm{C}$, температура автосемплера $20^{\circ} \mathrm{C}$. Объем вводимой пробы 20 мкл. Длины волн ДМД - 520 нм и 280 нм. Спектры снимали в диапазоне от 200 до 700 нм. Условия МС: напряжение на капилляре -3.5 кВ, поток газа-осушителя (азот) -9 дм $^{3} /$ мин, температура - $325^{\circ} \mathrm{C}$, давление на распылителе - 0.27 МПа, сканирование масс - в режиме регистрации положительных ионов [M] $]^{+}$в диапазоне от 100 до 1500 m/z. [5].

\section{Обсуждение результатов}

В качественном антоцианиновом составе всех исследуемых плодов не было найдено статистически значимых различий. Типичная хроматограмма одного из образцов представлена на рис.2.

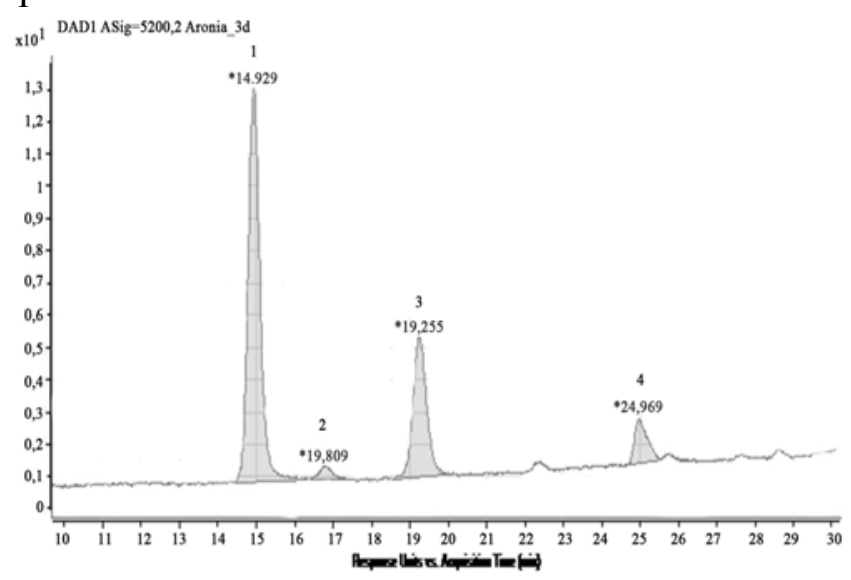

Рис. 2. Хроматограмма извлечения из плодов аронии черноплодной сорта «Вениса» при $\lambda=520$ нм. 1 - Цианидин-3-галактозид, 2 - Цианидин-3-глюкозид, 3 - Цианидин-3-арабинозид, 4 - Цианидин-3-ксилозид.

Параметры удерживания, массы молекулярных ионов индивидуальных антоцианов и их фрагментов в плодах аронии различных сортов представлен в табл.1.

Таблица 1. Результаты ВЭЖХ-МС анализа индивидуальных антоциановых соединений плодов рябины черноплодной различных сортов

\begin{tabular}{|c|c|c|c|c|}
\hline № & Антоцианин & $\mathrm{K}^{\prime *}$ & ESI-MS $^{+}$ & Детектируемый ион \\
\hline 1. & Цианидин-3-галактозид & 3.03 & $\begin{array}{l}449.10 \\
287.05\end{array}$ & $\begin{array}{c}{[\mathrm{M}]^{+}} \\
{[\mathrm{M}-\text { галактоза**}]^{+}}\end{array}$ \\
\hline 2. & Цианидин-3-глюкозид & 3.54 & $\begin{array}{l}449.10 \\
287.05\end{array}$ & $\begin{array}{c}{[\mathrm{M}]^{+}} \\
{[\mathrm{M}-\text { глюкоза }]^{+}}\end{array}$ \\
\hline 3. & Цианидин-3-арабинозид & 4.19 & $\begin{array}{l}419.09 \\
287.05\end{array}$ & $\begin{array}{c}{[\mathrm{M}]^{+}} \\
{\left[\mathrm{M}-{\text { aрабиноза }]^{+}}^{+}\right.}\end{array}$ \\
\hline 4. & Цианидин-3-ксилозид & 5.76 & $\begin{array}{l}419.09 \\
287.05 \\
\end{array}$ & $\begin{array}{c}{[\mathrm{M}]^{+}} \\
{\left[\mathrm{M}-{\text { ксилоза }]^{+}}^{-}\right.}\end{array}$ \\
\hline
\end{tabular}

*К' - коэффициент емкости; **Здесь и далее: молекулярная масса моносахарида минус 18 Да (молекула воды, теряющаяся при образовании гликозидной связи)

В масс-спектрах идентифицированных нами индивидуальных антоцианинов аронии в различных соотношениях присутствовали фрагменты агликонов. Профиль антоцианинов в анализируемых образцах (в \% от суммы антоцианинов) представлен в таблице 2. 
Таблица 2. Состав индивидуальных антоцианов в извлечениях из плодов рябины черноплодной различных сортов

\begin{tabular}{|c|c|c|c|c|}
\hline \multirow{2}{*}{ Сорт плодов аронии } & \multicolumn{4}{|c|}{ Состав индивидуальных антоцианинов (в \% от суммы антоцианинов) } \\
\cline { 1 - 5 } & $\begin{array}{c}\text { Цианидин-3- } \\
\text { галактозид }\end{array}$ & $\begin{array}{c}\text { Цианидин-3- } \\
\text { глюкозид }\end{array}$ & $\begin{array}{c}\text { Цианидин-3- } \\
\text { арабинозид }\end{array}$ & $\begin{array}{c}\text { Цианидин-3- } \\
\text { ксллозид }\end{array}$ \\
\hline «Викинг» & 62.8 & 3.3 & 29.0 & 4.9 \\
\hline $\begin{array}{c}\text { «Алтайская крупно- } \\
\text { плодная» }\end{array}$ & 60.6 & 3.6 & 30.5 & 5.3 \\
\hline «Вениса» & 63.8 & 2.3 & 26.3 & 7.6 \\
\hline «Мичуринская» & 71.4 & 2.8 & 22.1 & 3.7 \\
\hline
\end{tabular}

Все обнаруженные антоцианины являлись гликозидами цианидина. Во всех исследуемых сортах аронии преобладал цианидин-3-галактозид (60,6-71,4\%). Относительное содержание цианидин-3-арабинозида было в 2-3 раза меньше, чем цианидин-3-галактозида. Относительное содержание остальных антоцианинов (3ксилозида и 3-глюкозида цианидина) составило от 6.5 до 9.9\%. Существенных различий в содержании индивидуальных антоцианинов (в \% от суммы) между плодами аронии четырех изученных нами сортов выявлено не было.

Количественное определение суммы антоцианов в плодах аронии исследуемых сортов проводили методом спектрофотометрическим методом по ранее разработанной методике [6].

Экстракцию антоцианов проводили 40\%-ным спиртом этиловым на водяной бане с обратным холодильником в течение 60 минут, соотношение сырье: экстрагент 1:40. Полученные извлечения охлаждали до комнатной температуры, фильтровали, разбавляли и анализировали на содержание антоцианов на спектрофотометре «Hitachi U-1900» в максимуме поглощения $\lambda=533$ нм.

Содержание суммы антоцианов в пересчете на цианадин-3-О-глюкозид в абсолютно сухом сырье в процентах $(\mathrm{X})$ вычисляют по формуле:

$$
X=\frac{A \cdot 40 \cdot 25 \cdot 25 \cdot 100}{E \cdot a \cdot 5 \cdot 5 \cdot(100-W)}
$$

где А - оптическая плотность испытуемого раствора; а- навеска сырья, г; Е 1см $1 \%$ удельный показатель поглощения цианидин-3-О-глюкозида, равный 100 при 533 2 нм; W- потеря в массе при высушивании сырья, \%. Полученные данные представлены в табл.3.

Таблица 3 . Количественное содержание антоцианов в плодах Рябины черноплодной различных сортов

\begin{tabular}{|c|c|}
\hline Сорт плодов аронии & Содержание антоцианинов в плодах, \% \\
\hline «Викинг» & $1.30 \pm 0.10$ \\
\hline «Алтайская крупноплодная» & $0.98 \pm 0.09$ \\
\hline «Вениса» & $1.53 \pm 0.15$ \\
\hline «Мичуринская» & $3.70 \pm 0.37$ \\
\hline
\end{tabular}

Анализируя данные таблицы 3, можно сделать вывод о том, что плоды сорта «Мичуринская» лидируют по содержанию изучаемой группы соединений (содержание антоцианов в них превышает более, чем в 2 раза содержание в других образцах). 


\section{Заключение}

В результате проведенного исследования методом ВЭЖХ были идентифицированы основные и минорные антоцианины в плодах рябины черноплодной сортов «Викинг», «Алтайская крупноплодная», «Вениса» и «Мичуринская». Показано, что плоды рябины черноплодной различной сортовой принадлежности имеют одинаковый профиль антоцианинов. Основным компонентом антоцианов плодов аронии всех сортов является цианидин-3-галактозид (от 60.6 до 71.4\% от суммы антоцианинов). Максимальное содержание суммы антоцианинов (до 3.7 \%) найдено в плодах аронии сорта «Мичуринская».

\section{Список литературы}

1. Mazza G., Miniati E. Anthocyanins in fruits, vegetables and grains. Boca Raton: CRC Press Inc; 1993. 362 p.

2. Красильникова Л.А., Аксентьева О.А., Жмурко В.В. Биохимия растений. Ростов. Феникс. 2004. 224c.

3. Логвинова Е.Е., Брежнева Т.А.,. Самылина И.А, Сливкин А.И. // Фармация. 2015. № 6. С. 22-26.

\section{References}

1. Mazza G., Miniati E.. Boca Raton, CRC Press Inc, 1993, 362 p.

2. Krasilnikov L.A., Aksent'eva O.A., Zhmurko V.V., Rostov, Phoenix, 2004, 224 p.

3. Loginova E.E., Brezhneva T.A., Samylina I.A., Slivkin A.I. // Pharmitsia, 2015, №6, pp. 22-26.

4. http://www.rosminzdrav.ru/ministry/61/11/ materialy-po-deyatelnosti-

Логвинова Елизавета Евгеньевна - ассистент кафедры фармацевтической химии и фармацевтической технологии, фармацевтического факультета ВГУ, Воронеж

Брежнева Татьяна Александровна - доцент кафедры фармацевтической химии и фармацевтической технологии, к.фарм.н.; фармацевтического факультета ВГУ, Воронеж, тел.: (473) 2530428

Сливкин Алексей Иванович - д.ф.н., профессор, зав. кафедрой фармацевтической химии и фармацевтической технологии, декан фармацевтического факультета ВГУ, Воронеж

Перова Ирина Борисовна - к.ф.н., младший научный сотрудник лаборатории метаболомного и протеомного анализа ФГБУН «ФИЦ питания и биотехнологии», Москва

Эллер Константин Исаакович - д.Х.н., профессор, заведующий лабораторией метаболомного и протеомного анализа ФГБУН «ФИЦ питания Москва
4. http://www.rosminzdrav.ru/ministry/61/11/ materialy-po-deyatelnostideparatamenta/stranitsa-856/spisok-obschihfarmakopeynyh-statey

5. Перова И.Б. автореф. дис. М. 2015. 25 с.

6. Логвинова Е.Е., Брежнева Т.А., Сливкин А.И., Самылина И.А. // Вестник ВГУ, серия химия, биология, фармаџия. 2014. №1. С. 122-125.

deparatamenta/stranitsa-856/spisok-obschihfarmakopeynyh-statey

5. Perova I.B. avtoreferat. Dis., M., 2015, $25 \mathrm{p}$.

6. Loginova E.E., Brezhneva T.A., Slivkin A.I., Samylina I.A. // Bulletin of Voronezh State University, a series of chemistry, biology, pharmacy, 2014, No 1, pp. 122-125.

Logvinova Elizaveta E. - the assistant to chair of pharmaceutical chemistry and pharmaceutical technology, pharmaceutical faculty of VGU, Voronezh, e-mail: liza-ugl@mail.ru;

Brezhneva Tatyana A. - $\mathrm{PhD}$; the associate professor of pharmaceutical chemistry and pharmaceutical technology, pharmaceutical faculty of VGU, Voronezh, e-mail: t brezhneva@mail.ru

Slivkin Alexey I. - PhD. professor, department chair of pharmaceutical chemistry and pharmaceutical technology, dean of pharmaceutical faculty of VGU, Voronezh, e-mail: slivkin@pharm.vsu.ru.

Perova Irina B. - Ph.D., Researcher, Laboratory of metabolomic and proteomic analysis, Federal State Budgetary Scientific Institution "Federal Research Centre of Nutrition, Biotechnology and Food Safety", Moscow, e-mail: erin.feather@yandex.ru;

Eller Konstantin I. - Doctor of Chemistry, Professor, Head of the Laboratory of metabolomic and proteomic analysis, Federal State Budgetary Scientific Institution "Federal Research Centre of Nutrition, Biotechnology and Food Safety", Moscow, e-mail: ellki42@yandex.ru 